\title{
RREB1 wt Allele
}

National Cancer Institute

\section{Source}

National Cancer Institute. RREB1 wt Allele. NCI Thesaurus. Code C140255.

Human RREB1 wild-type allele is located in the vicinity of 6 p24.3 and is approximately 144 $\mathrm{kb}$ in length. This allele, which encodes Ras-responsive element-binding protein 1, plays a role in Ras signaling-dependent transcriptional regulation. 